\title{
OCENIANIE STOPNIA ZNAJOMOŚCI SLOWNICTWA W KONTEKŚCIE JEGO NAUCZANIA: RZECZYWISTOŚĆ, POTRZEBY, MOŻLIWOŚCI ${ }^{1}$
}

\begin{abstract}
Słowa kluczowe: testowanie/nauczanie słownictwa, kompetencja leksykalna, wiedza eksplicytna/implicytna, zadania komunikacyjne
\end{abstract}

Streszczenie. Stopień opanowania słownictwa przez uczących się języka polskiego na poziomach wyższych jest często sprawdzany za pomocą zadań, które w większym stopniu koncentrują się na znajomości form i znaczeń wyrazów, w mniejszym zaś na użyciu złożonych struktur leksykalnych. Ten rodzaj ewaluacji pozwala ocenić stan wiedzy deklaratywnej uczniów. Jest ona trudna do wyzyskania w autentycznych sytuacjach komunikacyjnych, w których spontaniczne działania wymagają od użytkownika wykorzystania wiedzy implicytnej. Celem niniejszego artykułu jest ogląd dydaktyki i ewaluacji słownictwa w języku polskim jako obcym dokonany z perspektywy potrzeb komunikacyjnych uczących się na poziomie średnim ogólnym. Zwraca się w nim uwagę na fakt, iż wiedza implicytna jest rezultatem głębokiej internalizacji słownictwa, a szybkie, fortunne reakcje użytkownika wspomaga właściwa organizacja leksykonu mentalnego, w którym, obok pojedynczych słów, magazynowane są różnej długości zespolenia (ciągi formuliczne). Pokazuje się też sposoby ukomunikacyjnienia obecnie stosowanych technik ewaluacji stopnia opanowania leksyki, a także proponuje takie, które opierają się na działaniach uwikłanych w kontekst i/lub w nim wyraźnie osadzonych.

\section{WPROWADZENIE}

Procedury wykorzystywane do oceny stopnia opanowania umiejętności językowych stanowią najczęściej odzwierciedlenie sposobów nauczania i w przypadku słownictwa bywają dość tradycyjne. Zdecydowana większość zadań stoso-

*anna.barbara.seretny@uj.edu.pl, Uniwersytet Jagielloński, Wydział Polonistyki, Instytut Glottodydaktyki Polonistycznej, ul. Grodzka 64, 31-044 Kraków.

${ }^{1}$ Inspiracją do napisania niniejszego tekstu był artykuł Pawlaka (2019a). Znany badacz procesów nauczania / uczenia się gramatyki poddał w nim analizie najczęściej stosowane obecnie sposoby sprawdzania stopnia opanowania tego podsystemu. Przemyślenia autora sprawiły, iż z podobnej perspektywy postanowiłam się przyjrzeć słownictwu. 
wanych w bezpośrednim testowaniu leksyki ${ }^{2}$ na poziomie recepcji oparta jest na zamkniętych jednostkach testu, gdyż takie uważa się za najbardziej obiektywne. W konsekwencji uczący się mają zaznaczyć odpowiednią formę/odpowiedź, połączyć elementy w całość, dokonać wykluczenia, wyboru itp. Jeśli sprawdza się znajomość słownictwa na poziomie produkcji, to zazwyczaj działania uczniów sprowadzają się do podania właściwego w danym kontekście wyrazu/połączenia, podpisania obrazka, dokonania parafrazy wskazanych wypowiedzi lub ich części itp. Czynności wykonywane w obu przypadkach, aczkolwiek niejednokrotnie oparte na złożonych operacjach umysłowych, których uruchomienie nie jest możliwe bez dobrej znajomości zagadnień językowych, tj. eksplicytnej wiedzy deklaratywnej, nie sprawdzają jednak tego, co najważniejsze - rzeczywistych umiejętności użycia słownictwa w autentycznych działaniach wymagających implicytnej wiedzy proceduralnej ${ }^{3}$. Relacje między obu rodzajami wiedzy były analizowane przez wielu badaczy, których stanowiska co do zakresu przekładalności tej pierwszej na drugą były bardzo różne ${ }^{4}$. Część zastanawia się nawet, czy da się w ogóle mówić o możliwości kształtowania się wiedzy nieuświadomionej u uczących się w warunkach szkolnych. Przeciwstawne stanowiska zdaje się godzić w pewnym stopniu propozycja Pawlaka (2019a), który sugeruje, by w kontekście glottodydaktycznym mówić o rozwijaniu wysoce zautomatyzowanej wiedzy eksplicytnej, która, zdaniem badacza, podobnie jak implicytna, może być dostępna w czasie rzeczywistym ${ }^{5}$.

Dotychczasowe sposoby bezpośredniego testowania słownictwa, w moim przekonaniu, nie sprawdzają zautomatyzowanej wiedzy eksplicytnej lub sprawdzają ją w bardzo niewielkim zakresie. $Z$ faktu, że w czasie egzaminu, czyli nierzeczywistym z punktu widzenia autentycznej komunikacji, uczący się uzupełnią brakujący w zdaniu wyraz, dokonają fragmentarycznej parafrazy, podpiszą obrazek, czy też zaznaczą właściwe w danym kontekście jednostki, nie wynika przecież, że w naturalnej sytuacji komunikacyjnej będą w stanie je szybko przywołać. A to właśnie umiejętność sprawnego przywoływania słów i ich kombinacji jest de facto pożądanym i oczekiwanym przejawem kompetencji leksykalnej

${ }^{2}$ Testowanie bezpośrednie to takie, w którym działania elicytowane od uczących się otwarcie skupiają się na określonych obszarach, na przykład na słownictwie. W testowaniu pośrednim natomiast staje się ono jednym z kryteriów oceniania lub jego znajomość stanowi niejawny, choć oczywisty warunek wykonania zadania (szerzej zob. Seretny 2015a). W niniejszym tekście mowa będzie tylko o testowaniu bezpośrednim, a zatem i o bezpośrednim nauczaniu.

${ }^{3}$ Wiedza eksplicytna obejmuje świadomą znajomość znaczenia i formy jednostki leksykalnej. Użycie „tego rodzaju wiedzy wymaga czasu, co oznacza, że o ile może zostać wykorzystana przy wykonywaniu ćwiczeń i na testach, jej przydatność w spontanicznej komunikacji jest bardzo ograniczona" (Pawlak 2019a, s. 174; zob. też Ellis 2005). Wiedza nieświadoma natomiast jest dostępna w czasie rzeczywistym i stanowi podstawę spontanicznych działań językowych.

${ }^{4}$ Szeroko pisze o tym Pawlak (2019b); tam też bogata literatura przedmiotu.

${ }^{5}$ Wykorzystane w niniejszym tekście sformułowania Pawlaka, choć odnoszą się do gramatyki i jej nauczania/testowania, są równie użyteczne w stosunku do podsystemu leksykalnego. 
użytkownika. Jej kształtowanie/rozwijanie powinno więc być celem wszelkich poczynań dydaktycznych i to ją przede wszystkim należałoby poddawać sprawdzaniu. W komunikacji rzadko przecież chodzi o wskazanie właściwego w danym kontekście słowa, czy też przekształcenie izolowanego zdania, lecz o takie postugiwanie się złożonymi strukturami leksykalnymi, które umożliwia użytkownikowi wyrażanie określonych treści (precyzja przekazu) celem realizacji konkretnych zamierzeń $i$ intencji (fortunność przekazu) w kontekśsie, w jakim komunikacja ma miejsce (stosowność przekazu). To zaś wymaga odpowiedniego zasobu środków językowych, do których dostęp musi przebiegać szybko i sprawnie. Ocenienie stopnia znajomości słownictwa, by pozostawało w zgodzie $\mathrm{z}$ faktycznymi potrzebami użytkownika, musi więc koncentrować nie tylko na ogólnej wiedzy deklaratywnej, której przejawem jest wspomniana umiejętność użycia wyrazów w różnego rodzaju ćwiczeniach, ale na tej zbliżonej do implicytnej, „która została w wysokim stopniu zautomatyzowana i może być używana w spontanicznej interakcji" (Pawlak 2019a, s. 172). Jeśli jednak chcemy, by opanowanie leksyki mogło być tak sprawdzane, musimy zmienić nieco sposoby jej nauczania, determinują one bowiem rodzaj zadań wykorzystywanych w testach badających kompetencję leksykalną i ich ukierunkowanie.

Celem niniejszego artykułu będzie ogląd rozwijania słownictwa w języku polskim jako obcym dokonanym z perspektywy potrzeb komunikacyjnych uczących się na poziomie B2, gdyż to wówczas musi dokonać się w u nich największy przyrost warstwy leksykalnej (zob. Seretny 2015b). Następnie zaproponowane zostaną sposoby ukomunikacyjnienia technik sprawdzania stopnia znajomości leksyki wykorzystywanych w testowaniu bezpośrednim, a także wskazane takie, które opierają się na rozwiązaniach bardziej przystających do potrzeb uczniów, wyrosłe na gruncie podejścia opartego na działaniach uwikłanych w kontekst i/lub w nim wyraźnie osadzonych.

\section{ZNAJOMOŚĆ SŁOWA W KONTEKŚCIE GLOTTODYDAKTYCZNYM}

Zanim przyjrzymy się sposobom nauczania słownictwa, konieczna jest refleksja nad konstruktem pojęciowym, jakim jest znajomość słowa. Jego rozumienie przekłada się bowiem z jednej strony na to, w jaki sposób leksyki się naucza i jak się ją testuje, $\mathrm{z}$ drugiej zaś - skutkuje określonym ukształtowaniem struktury leksykonu mentalnego (zob. Aitchison 1994), które umożliwia uczącym się mniej lub bardziej efektywny/elastyczny dostęp do zgromadzonych w nim zasobów.

Najczęściej znajomość słowa utożsamiana jest ze znajomością jego znaczenia. Nie jest to rozumienie błędne, lecz z pewnością niepełne. Znać słowo, to 
przecież nie tylko wiedzieć, co ono znaczy (FORMA FONICZNA/GRAFICZNA + ZNACZENIE), lecz przede wszystkim umieć się nim posługiwać (FORMA FONICZNA/GRAFICZNA + ZNACZENIE + UŻYCIE). Do tego zaś konieczne jest opanowanie form morfologicznych wyrazów, a także ich łączliwości składniowej oraz semantycznej. W wielu kontekstach przydaje się także wiedza, jakimi innymi jednostkami można je zastąpić, jakie mają do nich znaczenie podobne. Ważna jest też świadomość, do jakiego stylu funkcjonalnego należą oraz to, że najczęściej bywają wieloznaczne i niosą (lub nie) określone konotacje, które mogą u współużytkowników wywoływać pewne skojarzenia (zob. Richards 1976; Nation 2001; Dźwierzyńska 2012; Seretny 2015a). Nośnikami tak rozumianego znaczenia są w języku nie tylko pojedyncze słowa, lecz także, według wielu autorów (zob. m.in. Lewis 1997), a w tym twórców Europejskiego systemu opisu ksztatcenia językowego (2003), różnej długości jednostki wielowyrazowe, tj. wyrażenia idiomatyczne oraz rozmaite utarte połączenia (zwroty, frazy, wyrażenia). Funkcjonują one w słowniku mentalnym użytkownika jako całostki, zwane też ciągami formulicznymi (zob. Wray 2002), tworząc mozaiki o uporządkowaniu wertykalno-horyzontalnym, a także schodkowym, łańcuszkowym, gwiaździstym (zob. Aitchison 1994). W ciągi linearne są zaś układane zgodnie $z$ regułami systemu oraz uzusu. Aby w pełni opanować określoną całostkę (jedno- lub wieloelementową), uczący się musi więc wiedzieć:

- co ona oznacza (aspekt semantyczny),

- jak jest skonstruowana (aspekt poprawnościowy w odniesieniu do form morfologicznych oraz łączliwości składniowej i semantycznej),

- w jakich sytuacjach i w jakim celu jest używana (aspekt socjo- i pragmalingwistyczny).

Przyjęcie takiego rozumienia znaczenia słowa i jego nośników w sposób naturalny skutkuje uwzględnianiem go w procesie nauczania leksyki, a co za tym idzie - jej uczenia się i oceniania. To jednak nie zawsze ma miejsce.

Nie ulega wątpliwości, iż z triady: forma, znaczenie, użycie trudniejsze do opanowania są elementy pierwszy i trzeci niż drugi, na którym najczęściej koncentruje się nauczanie. Forma, gdyż wymaga przyswojenia (na poziomie eksplicytnej wiedzy deklaratywnej) nie tylko kształtów graficznych/fonicznych pojedynczych wyrazów, lecz także ciągów funkcjonujących w pamięci rodzimych użytkowników języka, utrwalonych przez uzus, a częstokroć zupełnie innych

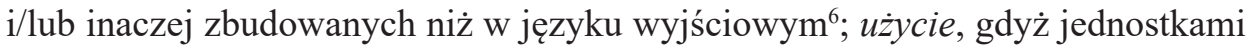
zapisanymi w słowniku mentalnym trzeba umieć się posługiwać, czyli dobierać je poprawnie, adekwatnie do sytuacji, czyniąc to sprawnie, a docelowo - niemal bezwiednie (przejaw zautomatyzowanej wiedzy eksplicytnej). Do tego zaś konieczna jest praktyka, korzystanie $\mathrm{z}$ danych zapisanych $\mathrm{w}$ słowniku mental-

\footnotetext{
${ }^{6}$ Por. chociażby angielskie to have butterflies in one's stomach i polskie denerwować się.
} 
nym jest bowiem tym efektywniejsze, im bardziej 'wypracowana' ścieżka dostępu do nich. Dzięki badaniom neurobiologicznym wiemy, że uczenie się jest swego rodzaju rzeźbieniem w neuronalnym substracie. Ukształtowanie sieci neuronalnych, tj. ich struktura i siła połączeń synaptycznych między tworzącymi je neuronami, zależy od wielu czynników; do najważniejszych należą jednak: częstość, intensywność i rodzaj doświadczeń z określonymi treściami oraz czas, jaki na ich uczenie się przeznaczamy (zob. Fields 2004). Oznacza to, że niemożliwe jest osiągniecie biegłości w czymkolwiek, w tym także w posługiwaniu się słowami, bez intensywnej pracy i nieustannej praktyki.

\section{NAUCZANIE LEKSYKI - RZECZYWISTOŚĆ A POTRZEBY}

Podsystem leksykalny nie budzi w dydaktyce polszczyzny tylu dyskusji, ile gramatyka. Pełni też w stosunku do niej funkcję służebną. To system gramatyczny stanowi najczęściej kluczowy punkt odniesienia przy opracowywaniu materiałów dydaktycznych: zwraca się uwagę na kolejność nauczania przypadków, czasów, trybów; obecności określonych zagadnień gramatycznych (zob. Janowska i in. 2011, 2016; Standardy wymagań egzaminacyjnych 2016) oczekuje się w podręcznikach i to ich opanowanie stanowi najpierw cel nauczania, a następnie ewaluacji na kolejnych etapach kształcenia. W dydaktyce słownictwa, inaczej niż w nauczaniu gramatyki, w wielu kwestiach panuje spora dowolność.

\subsection{TREŚCI NAUCZANIA}

Leksykalnymi jednostkami nauczania, niezależnie od etapu kształcenia, w dalszym ciągu częściej są pojedyncze słowa niż wielowyrazowe, utrwalone przez uzus ciągi (wystarczy tu pobieżna lektura większości kursowych podręczników do nauczania polszczyzny, by przekonać się, jak wiele w tej materii jest jeszcze do zrobienia ${ }^{7}$ ). Zakresy leksyki przewidywane jako docelowe na poszczególnych poziomach są wyznaczane ogólnikowo. Na A1 na przykład należy opanować około 1000-1500 jednostek z określonych zakresów tematycznych, nie wskazuje się jednak „których jednostek”. Frekwencja jako kryterium doboru lek-

\footnotetext{
${ }^{7}$ Prezentacja analizy podręczników kursowych do nauki polszczyzny wykracza poza ramy niniejszego artykułu, lecz została przez autorkę przeprowadzona w zakresie badań własnych.

${ }^{8}$ Autorzy materiałów, nawet jeśli deklarują, że przedmiotem nauczania w danym podręczniku jest tzw. leksyka często używana, to termin ten rozumieją w najlepszym razie nie dość ściśle (zob. np. Mirocha 2019).
} 
sykalnych treści nauczania w glottodydaktyce polonistycznej nie doczekała się na razie uznania, jakim cieszy się w światowej; u nas do kolejnych etapów biegłości przynależą jedynie obszary tematyczne, które, w miarę rosnącej biegłości uczących się stają się coraz pojemniejsze (zob. Janowska i in. 2011, 2016). Ustalenie leksykalnych wyznaczników poziomów zaawansowania językowego ${ }^{9}$ pozwoliłoby zaś nauczycielom mniej intuicyjnie odpowiadać na pytanie, czy dane słowo /wyrażenie powinno być znane uczącym się na B2, na C1 czy C2. Dzięki listom wyrazów 'przypisanych' do poszczególnych etapów kształcenia możliwe byłoby nie tyle określanie poziomu ich umiejętności językowych, ile właściwe diagnozowanie wielkości zasobu leksykalnego. Z faktu, że ktoś zna słowo zdążyć / nie zna słowa $z$ dażyć nie wynika przecież, że jest lub nie jest na poziomie A1, lecz raczej, że jego kompetencja leksykalna rozwija się mniej lub bardziej prawidłowo (leksem ten należy do najczęściej używanych, mieści się w przedziale 1-1000; zob. Seretny 2011a). Jeśli więc wyrazu tego nie opanował, powinien poznać go jak najszybciej, tj. przed innymi, mniej ważnymi, w komunikacji codziennej pojawiającymi się zdecydowanie rzadziej.

\subsection{UKIERUNKOWANIE I RODZAJ INTERWENCJI DYDAKTYCZNEJ}

Dobór treści nauczania jest rzeczą ważną, lecz równie istotny jest tryb pracy nad nimi, czyli rodzaj i ukierunkowanie interwencji dydaktycznej. W tym miejscu warto zaznaczyć, iż nauczanie słownictwa na każdym z etapów kształcenia językowego, ze względu na określone potrzeby użytkowników, ma swoją specyfikę, której nie sposób kwestionować. Konieczność umożliwienia uczącym się podejmowania podstawowych działań i jak najszybszego zapewnienia im 'samodzielności’ komunikacyjnej sprawia, iż na najniższym poziomie zaawansowania (A) nauczanie leksyki z natury rzeczy musi koncentrować się na aspekcie ilościowym. Nauczanie takie określa się mianem wszerz, gdyż skupia się na poznawaniu przez uczniów form, ich podstawowych znaczeń i użycia coraz większej liczby jednostek leksykalnych (w zdecydowanej większości jednoelementowych). Dzięki ich opanowaniu możliwe stają się wymiany w typowych sytuacjach: uczący się stawiają w języku pierwsze, ostrożne kroki, przy których najważniejsza jest nośność i skuteczność przekazu. Jego poprawność i fortunność, przez Sinclaira (1991) rozumiana jako idiomatyczność, na tym etapie słusznie pozostają nieco $\mathrm{w}$ tle. W miarę jednak jak rośnie biegłość językowa uczniów i w grę wchodzi już nie tylko przysłowiowe 'dogadywanie się', lecz idzie o możliwość precyzyjniejszego wyrażania własnych chęci, dążeń, przeżyć, pragnień czy intencji (zob. ESOKJ,

\footnotetext{
${ }^{9}$ Przez lata bezskutecznie próbowałam doprowadzić do ustalenia takiego zasobu w ramach działań okołocertyfikatowych.
} 
2003), samo nauczanie wszerz przestaje wystarczać. Od poziomu B1.2 powinno więc zacząć mu towarzyszyć nauczanie $w$ głąb. Chodzi bowiem o to, by:

- język uczących się coraz bardziej przypominał ten, którego używają na co dzień rodzimi użytkownicy ${ }^{10}$;

- wypowiedzi uczniów były nie tylko komunikacyjnie nośne i zgodne z ich intencjami, lecz w danym kontekście fortunne i precyzyjne;

- uczniowie umieli wyrazić te same treści na różne sposoby w zależności od tego, do kogo i w jakim celu mówią.

Kumulacja równoległości obu wymiarów kształtowania kompetencji leksykalnej uczących się ma miejsce na poziomie B2, na którym musi dokonać się podwojenie ich dotychczasowego leksykalnego stanu posiadania. Oznacza to, że zasobność słownika mentalnego z opanowanych łącznie na poziomach A1-B1 około 3500 jednostek leksykalnych powinna wzrosnąć do przynajmniej około 7000 (zob. Seretny 2015b), przy czym ich znajomość nie może ograniczać się do formy i użycia w podstawowym znaczeniu. Na poziomie B2, a potem rzecz jasna na $\mathrm{C} 1$ i $\mathrm{C} 2$, coraz większego znaczenia nabiera bowiem precyzja i fortunność wyrażania intencji. I tak, przykładowo, uczący się powinni wiedzieć, że oddycha się górskim, a nie *górzystym powietrzem (choć krajobraz może być i górzysty, i górski), że z trudnościami można się mierzyć, a nie jedynie je mieć; powinni też umieć nawiązać do tego, co wcześniej zostało powiedziane, wiedzieć, że jabłka są zgnite, dojrzate, zepsute, mają skórkę, ogonek, a po ich zjedzeniu zostaje ogryzek. Byłoby też dobrze, by na koniec B2 nie tyle bali się, bo jest dziwnie cicho, a wcześniej było głośno, ile by byli przerażeni z powodu, ciszy, która właśnie zapadta. Jeśli zaś chcą stwierdzić, iż pięćdziesięcioletnia osoba jest stara, to ma być to wynik realizacji ich zamierzenia komunikacyjnego, a nie przejaw braku znajomości innego znaczenia przymiotnika dojrzały, czy wyrażenia $w$ dojrzałym wieku.

Uczący się muszą więc przyswoić bardzo dużo nowej leksyki, a także coraz więcej wiedzieć o jej użyciu oraz o użyciu tej, którą już opanowali. Poznane/ poznawane słownictwo powinno zaś tworzyć, jak już wspomniałam, konstelacje wzajemnie powiązanych jedno- i wieloelementowych jednostek, które, by mogły być swobodnie przywoływane w czasie rzeczywistym, muszą najpierw w takich konfiguracjach zostać w słowniku zakodowane.

Konieczność podwojenia zasobu powiązanego jednocześnie z intensywnymi zmianami jakościowymi w obrębie poszczególnych tworzących go elementów sprawia, że proces opanowywania leksyki od poziomu B2 jest nieporównanie trudniejszy, bardziej pracochłonny niż na etapach wcześniejszych, o czym nie dość wyraźnie uczący się są informowani. Zdecydowanie za mało podejmuje się działań na rzecz podnoszenia poziomu ich autonomii. Materiał leksykalny na po-

${ }^{10}$ Podobnie jak Komorowska (2019, s. 19) uważam, iż nie jest realne ,pominięcie biegłości idealnego native-speakera jako punktu odniesienia wysokiej sprawności językowej”, nawet jeśli przyjmiemy, że nie jest on „modelem do bezkrytycznego odwzorowywania”. 
ziomach B2-C2 jest tak duży, iż rola nauczyciela, siłą faktu, sprowadzać się może co najwyżej do kierunkowania procesu uczenia się, tj. do zwracania uwagi na to, co ważne, czy też inicjowania i/lub wskazywania działań, które mogą sprzyjać powstawaniu w pamięci odpowiednich powiązań. Obiegowa opinia głosi, że gdy nowe słowo zobaczymy średnio 4 razy, 4 razy je powiemy, 4 razy je usłyszymy i 4 razy przeczytamy (w różnych kontekstach i odstępach czasu), nie będziemy musieli wkładać już żadnego wysiłku, by je zapamiętać. Trudno znaleźć dane potwierdzające to stwierdzenie ${ }^{11}$, lecz osiągnięcie nawet 16-krotnego zróżnicowanego kontaktu z tą samą jednostką na zajęciach, całkiem możliwe na poziomie A1, na B2 jest nierealne. Bez większego zaangażowania ze strony samych uczniów, a przede wszystkim bez intensywnej, systematycznej pracy indywidualnej poza zajęciami, nietrudno będzie im utknąć w ciemnościach leksykalnego tunelu (zob. Seretny 2015b), gdyż ślady słów w ich leksykonie mentalnym samoistnie nie staną się trwalsze, a tylko takie umożliwiają sprawniejsze przywoływanie jednostek w aktach komunikacji. Wielokrotnego kontaktu, zróżnicowanych doświadczeń same lekcje nie zapewnią. Uczeń na B2 musi więc działać sam, a nie jedynie pod dyktando nauczyciela.

\subsection{OBSZAR ZANIEDBYWANY}

O powyższych zagadnieniach pisałam już wcześniej (zob. Seretny 2005, 2015a, 2015b; Seretny, Stefańczyk 2015), chciałbym jednak raz jeszcze powrócić do jednego $z$ nich. Jest nim potrzeba zwrócenia w dydaktyce baczniejszej uwagi na złożoność struktur leksykalnych na osi syntagmatycznej, czyli na zjawisko formuliczności wypowiedzi, będącej wynikiem użycia w niej nie tylko pojedynczych wyrazów, lecz także ustanowionych przez uzus ciągów. W dydaktyce są obecne jedynie wyrażenia idiomatyczne (ze względu na ich semantyczną nieprzejrzystość) leksykalnymi jednostkami nauczania zbyt rzadko natomiast stają się kolokacje, utarte sformułowania/frazy, które w umysłach rodzimych użytkowników funkcjonują jako zespolenia (swego rodzaju 'prefabrykaty'), utrwalane /utrwalone wskutek nieustannych doświadczeń. Ich obecność niejednokrotnie jest miarą idiomatyczności i naturalności przekazu (zob. Sinclair 1991). Dzięki nim można posługiwać się językiem sprawniej, gdyż przetwarzane holistycznie znacznie mniej obciążają mało pojemną pamięć krótkotrwałą (Pawley, Syder 1983).

${ }^{11}$ Zob. http://www.prestonschool.pl/blog/jak-zapamietac-slowa-w-jezyku-obcym-na-zawsze/ [03.09.2020]. Dotarłam jedynie do pracy J. Coady’ego (1993, s. 12) poświęconej wprowadzaniu słownictwa. Badacz uważa, że nowy wyraz powinien pojawić się na lekcji minimum 4 razy w różnych kontekstach, ale w tym samym znaczeniu i przynajmniej raz - w trzech lekcjach następujących po niej, czyli łącznie 7 razy. 
Trzeba zatem dołożyć wszelkich starań, by słownik mentalny uczących się kształtować w tym względzie właściwie, by jak rodzimi użytkownicy w większym zakresie mogli korzystać z zespoleń/ciągów. W innym razie, co prawie 30 lat temu trafnie skonstatował często przeze mnie przywoływany Kjellmer (1991, s. 124), „za cenę prefabrykatów będą otrzymywali pojedyncze cegły”, a generując połączenia element po elemencie, niechybnie naruszą normy łączliwości semantycznej i w rezultacie ich komunikat, choć 'zmieści się w systemie', dla rodzimych użytkowników nie będzie brzmiał 'dobrze' (np. Proszę mi *zaznaczyć bilet).

Ukształtowaniu słownika mentalnego, które umożliwia sprawniejszą i bardziej ‘formuliczną’ produkcję (zob. Sinclair 1991; Wray 2002), sprzyjają, między innymi:

- podniesienie rangi sprawności receptywnych, gdyż nieodzowną podstawą naturalnie brzmiącej produkcji jest proces odpowiednio ukierunkowanej recepcji (zob. Dakowska 2001; Seretny 2013a, 2013b);

- uwrażliwianie uczących się na obecność w tekstach jednostek wielowyrazowych, na ich strukturę, funkcję i uwikłanie kontekstowe (zob. Lewis 1997; Seretny 2011b, 2015a, 2015b);

- bezpośrednie ich nauczanie (zob. Seretny 2016), czyli bezpowrotne porzucenie przekonania, iż słownictwo utrwali się samoistnie przy okazji / w toku ćwiczeń sprawnościowych.

Uczący się muszą więc dużo czytać i słuchać, także samodzielnie, na zajęciach zaś należy im wyraźnie zwracać uwagę na połączenia właściwe danemu typowi dyskursu. Analiza budowy, znaczenia, konotacji ciągów zdecydowanie zwiększa prawdopodobieństwo ich zapamiętania, pozwalając tym samym na przywołanie połączenia w pożądanym kształcie w czasie produkcji językowej (zob. m.in. Sinclair 1991; Lewis 1997). Należy też utrwalać je za pomocą zadań wyraźnie na nich skoncentrowanych, a następnie elicytować w wypowiedziach. Działania takie, będące przejawem nauczania eksplicytnego ${ }^{12}$, przyczyniają się bowiem do zdecydowanie lepszego opanowania materiału (zob. Pawlak 2019a, s. 175).

\section{SPRAWDZANIE/TESTOWANIE ZNAJOMOŚCI SEOWNICTWA - RZECZYWISTOŚĆ A POTRZEBY}

Na B2 i poziomach wyższych dominuje pośredni sposób badania zasobu leksykalnego uczących się. Zasadność takiego rozwiązania opiera się na słusznym skądinąd przekonaniu, iż środki słownikowe opanowuje się po to, by wykorzysty-

${ }^{12}$ Jego przeciwieństwem jest nauczanie incydentalne (pośrednie), w którym uwaga uczących się skupia się na innych niż słownikowe zagadnieniach, np. na wiadomości komunikowanej przez mówiącego lub piszącego, na zdobywaniu, przekazywaniu informacji itp. 
wać je w działaniach językowych: receptywnych, produktywnych, interakcyjnych i mediacyjnych. Takie podejście do komponentu leksykalnego powoduje jednak, iż nie zyskuje on w oczach uczących się właściwej mu rangi, część zadań na teście często są bowiem w stanie wykonać bez znajomości określonych wyrazów i ich połączeń. Podczas recepcji posiłkują się inferencją leksykalną, a w czasie produkcji wykorzystują słownictwo dobrze już znane z poziomów niższych lub stosują strategię uniku.

Do regularnej i intensywnej pracy nad słownictwem nie do końca skłaniają też uczniów sposoby bezpośredniej weryfikacji stopnia jego opanowania, choć w istocie rzeczy pozwalają sprawdzić, czy uczący się przyswoili wiele rozmaitych aspektów znajomości jednostek, w tym między innymi, czy (zob. Seretny, 2015a):

- pamiętają ich znaczenie,

- wiedzą, że w zależności od kontekstu jednostki mogą mieć wiele znaczeń,

- znają ich konotacje,

- potrafią przyporządkować je do określonej kategorii tematycznej i/lub znaczeniowej,

- znają połączenia jednostek, w jakie zazwyczaj wchodzą,

- umieją utworzyć od nich jednostki pochodne,

- wiedzą, że mogą się one różnić stopniem natężenia cechy,

- znają zależności między określonymi jednostkami (antonimii, synonimii itp.),

- potrafią je przywołać do wykonania określonego zadania,

- potrafią zastąpić je innymi, zachowując znaczenie przekazu,

- znają ich odpowiedniki w swoim języku.

Choć ukierunkowanie technik jest zróżnicowane, ich wachlarz - szeroki i znany $\mathrm{z}$ lekcji ${ }^{13}$, to jednak wyniki uzyskane $\mathrm{w}$ ewaluacji nie zawsze $\mathrm{w}$ pełni odzwierciedlają faktyczny 'leksykalny stan posiadania' uczących się - ich wypowiedzi często cechuje nieporadność mimo dobrych ocen z testów słownikowych $^{14}$. Dzieje się tak z kilku powodów. Po pierwsze, w sprawdzianach wykorzystuje się niewiele technik. Z ponad dwudziestu możliwych (zob. Dźwierzyńska 2012; Seretny 2015a) do ewaluacji poleca się jedynie cztery uznawane za najbardziej obiektywne (zob. np. Janowska i in., 2011, 2016). Są to: wybór wielokrotny, dobieranie (poziom recepcji), wypełnianie luk, transformacja słowotwórcza (poziom produkcji). Uczniowie, wiedząc więc, jak znajomość leksyki będzie weryfikowana, pod kątem takich sprawdzianów się przygotowują. Po drugie, zadania testowe często koncentrują się na słownictwie z wybranych obszarów tematycznych, wyniki są zaś ekstrapolowane na wszystkie, które sta-

${ }^{13}$ Zgodność technik testowania i nauczania jest jednym z podstawowych wymogów trafnej i rzetelnej kontroli wyników.

${ }^{14}$ Analiza wypowiedzi uczących się na poziomie B2 z testów osiągnięć oraz części sprawdzających opanowanie słownictwa w CJKiPwŚ, UJ (niezweryfikowane dane naukowe). 
nowiły treści kształcenia. Powodem trzecim, i najważniejszym, jest zaś to, że nauczyciele nie do końca wykorzystują potencjał samych technik. Zastrzeżenia budzi przede wszystkim pożytkowane w nich tworzywo, czyli wielkość, złożoność oraz rodzaj materiału wyjściowego. Zadania testujące bardzo często składają się z izolowanych zdań, w których operuje się niepowiązanymi, oderwanymi znaczeniowo strukturami (np. każde sprawdza znajomość innego idiomu lub pojedynczych wyrazów z różnych pól tematycznych). Płaszczyznę zdania z pewnością można uznać za jeden z poziomów kształtowania i oceny sprawności językowej, nie jest ona jednak wystarczająca (zob. Dyduchowa 1988, s. 38), szczególnie na poziomach wyższych.

Reasumując: testowanie bezpośrednie, opierając się na nie dość zróżnicowanym doborze technik, a przede wszystkim na ograniczonym i niepowiązanym materiale wyjściowym, nie ma charakteru komunikacyjnego. Poddaje więc ewaluacji, i to dość fragmentarycznej, jedynie wiedzę deklaratywną uczniów, ważną, lecz łatwiejszą do opanowania, znacznie trudniejszą zaś do spożytkowania podczas spontanicznych działań językowych.

\subsection{KU BARDZIEJ KOMUNIKACYJNEMU TESTOWANIU SŁOWNICTWA - PROPOZYCJE DYDAKTYCZNE}

Skoro w taki sposób najczęściej testuje się znajomość słownictwa, to za pomocą podobnych sposobów się go naucza (klasyczny efekt zwrotny), a przecież celem działań dydaktycznych nie ma być kształtowanie umiejętności poprawnego rozwiązywania ćwiczeń testowych, lecz umiejętność wykorzystania określonych struktur dla zrealizowania konkretnej intencji komunikacyjnej w kontekście pozaklasowym. Uczący się zaś mogliby być do tego lepiej przygotowani, gdyby bezpośrednie testowanie znajomości słownictwa miało charakter bardziej komunikacyjny. Zanim przedstawię kilka przykładowych rozwiązań, postaram się wyjaśnić, jak powyższe określenie rozumiem. Jest to mianowicie taki rodzaj ewaluacji, w której materiał wyjściowy stanowią teksty ${ }^{15}$, a nie zdania czy wyrazy (warunek konieczny). Działania podejmowane na ich podstawie przez uczących się powinna cechować autentyczność sytuacyjna ${ }^{16}$, (warunek pożąda-

${ }^{15}$ Tekst rozumiany za Bartmińskim (2004, s. 10) jako jednostka ponadzdaniowa mająca określone nacechowanie gatunkowe i stylowe, poddająca się całościowej interpretacji semantycznej i komunikatywnej, wykazująca integralność strukturalną oraz spójność semantyczną i podlegająca wewnętrznemu podziałowi semantycznemu, a w przypadku tekstów dłuższych - także logicznemu i kompozycyjnemu.

${ }^{16}$ Czyli powinny być one jak najbardziej zbliżone to tych, które mogłyby mieć miejsce w rzeczywistości. 
ny), a ich realizację w czasie zbliżonym do rzeczywistego (warunek pożądany) ${ }^{17}$ ma umożliwić znajomość i umiejętność posługiwania się określonymi strukturami leksykalnymi (warunek konieczny). Im więcej zatem warunków spełnią zadania wykorzystywane w ewaluacji, tym wyższy będzie stopień ich komunikacyjności.

W jakim kierunku powinny więc pójść zmiany w obszarze testowania bezpośredniego? Moim zdaniem, zadania sprawdzające muszą, po pierwsze, w nieco inny sposób koncentrować się na egzekwowaniu wiedzy deklaratywnej, po drugie zaś, umożliwiać poddawanie ocenie także tę już zinternalizowaną. Można tego dokonać poprzez poszerzenie zakresu technik stosowanych w ewaluacji zasobów słownikowych uczących się, przy jednoczesnej dbałości o ich komunikacyjność, a także dzięki uzupełnieniu go o nowe, mniej konwencjonalne.

W ocenianiu receptywnej i produktywnej znajomości słownictwa (w testowaniu bezpośrednim) wykorzystuje się techniki oparte na bodźcu wizualnym lub werbalnym, przy czym na wyższych poziomach zaawansowania - głównie te drugie (zob. Dźwierzyńska 2012; Seretny 2015a). Ich ukomunikacyjnieniu służą zupełnie proste działania, czyli: uczynienie materiałem wyjściowym tekstu, osadzenie zadania w kontekście bliskim uczącym się i przypisanie im w działaniach ról bardziej dla nich naturalnych, np. chorego, a nie lekarza, petenta, a nie urzędnika, a także nadanie wykonaniu zadania konkretnych ram czasowych $^{18}$ (przekazywanie treści w sposób spontaniczny lub pod presją czasu jest jedną $\mathrm{z}$ istotnych cech komunikacji międzyludzkiej). Procedura ukomunikacyjniania została pokazana poniżej na przykładzie fragmentów klasycznych zadań: zamkniętego (I) i częściowo otwartego, (II) zaczerpniętych z mojego podręcznika (zob. Seretny 2016), które w ewaluacji leksyki stosowane są rzadziej. Pierwsze, na pozór mało komunikacyjne, sprawdza $w$ istocie rzeczy ważną $w$ interakcjach umiejętność stwierdzania, czy dany komunikat wnosi coś nowego, czy też jest powtórzeniem informacji; drugie z kolei, służy usprawnianiu mechanizmu antycypacji, bez którego trudno mówić o biegłym rozumieniu ze słuchu (zob. Prizel-Kania 2013).

\section{Czy znaczenie podanych par jest takie samo (TS) czy różne (R)?}

$\begin{array}{lcc}\text { Przykład: } \quad \text { wyruszyć w podróż-planować wyjazd } & \text { TS } & \boldsymbol{R} \\ \text { 1. wycieczka - wędrówka } & \text { TS } & \text { R } \\ \text { 2. pełnia sezonu - czas, w którym wszyscy spędzają urlop } & \text { TS } & \text { R }\end{array}$

${ }^{17}$ Jest to więc specyficzna odmiana testu szybkości (zob. Glosariusz..., 2004).

${ }^{18}$ Testy tradycyjne wykonuje się, co prawda, w określonym czasie, ale w większości przypadków kolejność działań nie jest ustalona, nie ma też możliwości stwierdzenia, przy którym podejściu dana jednostka została wykonana, ile po drodze było korekt itp. 
Ia. Czy znaczenie wskazanych par jest takie samo (TS) czy różne (R)? Pierwsze rozwiązanie jest przykladem. Proszę wykonać zadanie w . . . . minut.

\begin{tabular}{|l|l|c|c|}
\hline $\begin{array}{l}\text { Gosia } \\
\text { Tomek }\end{array}$ & $\begin{array}{l}\text { Zaplanowałam już cały wyjazd, jeszcze tylko kilka drobiazgów ... } \\
\text { Kiedy wyruszasz w podróż życia? }\end{array}$ & TS & R \\
\hline $\begin{array}{l}\text { Gosia } \\
\text { Tomek }\end{array}$ & $\begin{array}{l}\text { Wycieczka jest na początku lipca. } \\
\text { (śpiewa) Wẹdrówka, drówka, rówka, ówka, wka, ka, a, bo o niej } \\
\text { właśnie jest piosenka ta, ta, }\end{array}$ & TS & R \\
\hline Gosia & $\begin{array}{l}\text { Oj, przestań. Nie wiem tylko, czy dobrze robię, że jadę w lipcu, bo } \\
\text { to czas, w którym wszyscy spędzają urlop... }\end{array}$ & TS & R \\
Tomek & Nie każdy lubi pełnię sezonu. & \\
\hline
\end{tabular}

II. Proszę uzupełnić brakujące wyrazy, pamiętając o ich poprawnej formie.

Przyklad: Jutro mam test z historii. Muszę się ... uczyć...

1. Marku, jaką metodę $\mathbf{z}_{-} \ldots$

2. Ewa ma matematykę w małym $\mathbf{p}_{\ldots--\_}$.

IIa. Proszę uzupelnić brakujące wyrazy, pamiętając o ich poprawnej formie. Pierwsze rozwiązanie jest przykładem. Proszę wykonać zadanie w .... minut.

Kasia: Jutro jest test z historii. Muszę się ... uczyć...Tobie to dobrze, historię masz

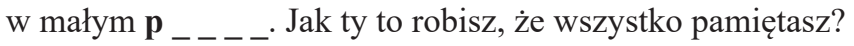

Emilka: $\mathbf{S}_{-\ldots} \ldots$ __ strategie.

Kasia: Czyli?

Proponowane zadania należy wykonać w określonym czasie. Wyznaczy go nauczyciel, który zna swoją grupę i tryb jej pracy. Ważne jest jednak, by był to czas mocno ograniczony.

Możliwości komunikacyjnego sprawdzania produktywnej znajomości słownictwa otwierają natomiast rzadziej w testowaniu stosowane zadania oparte na luce informacyjnej. Jej potencjał jest w dydaktyce języka często niedoszacowany, a stanowi ona przecież naturalny element codziennej komunikacji. Zadania z luką, które można wykorzystać dla celów ewaluacji warstwy leksykalnej, to na przykład:

- opisywanie obrazka przez dwie osoby, które mają różne jego fragmenty; negocjacja znaczeń sprzyja aktywacji słownictwa zinternalizowanego (zob. Ellis 2005);

- wspólna rekonstrukcja tekstu, którego różne fragmenty ma uczący się A i B; 
- spontaniczne dialogi uczących, w których każdy uczestnik dostaje informacje nieznane drugiemu, a niekiedy także krótkie teksty na temat $\mathrm{X}$, wynikający z zajęć (np. A dzwoni do B z propozycją spotkania, B jest chory i potrzebuje określonego lekarstwa $\mathrm{z}$ apteki, A nie jest chętny do pomocy, gdyż ...; A przeczytał właśnie ciekawy tekst, który chce opowiedzieć B, B przeczytał tekst na podobny temat, ale stanowisko autora było inne - dyskutują);

- szczegółowy opis fotografii, w którym trzeba w określonym czasie uwzględnić wszystkie elementy zaznaczone kropką lub, w grupach jednojęzycznych, zapisane w J1 uczących się.

W grupach jednojęzycznych można także:

- polecić uczącym się jak najszybsze przeczytanie tekstu z lukami, w których ciągi w ich J1 trzeba szybko zamieniać na odpowiadające im jednostki w języku polskim (na przykład Once upon a time w małym miasteczku ....); tłumaczenie jest ważną umiejętnością, której opanowanie wymaga ćwiczeń; mediacja międzyjęzykowa pozwala uczącym się w pełni uświadomić sobie, że znajomość ekwiwalentów wyrazów tworzących teksty jest warunkiem koniecznym, ale niewystarczającym, by thumaczenie było fortunne;

- wykorzystać translanguaging; uczący się dostają wówczas tekst w J1, który mają przeczytać/opowiedzieć/streścić po polsku; warunkiem powodzenia tego zadania jest odpowiedni jego dobór, gdyż stopień trudności musi być na poziomie $i-1$.

Zadania te nie są obce ani uczącym, ani uczącym się, wykorzystuje się je bowiem w celu rozwijania sprawności mówienia. W czasie ćwiczeń sprawnościowych na plan pierwszy wysuwa się jednak komunikacyjna nośność wypowiedzi oraz osiągnięcie celu; zastosowane środki, w tym leksykalne, stanowią zaś jedynie jedno z kryteriów oceniania (testowanie pośrednie). W przedstawionej propozycji natomiast zyskałyby priorytet, gdyż to one w pierwszym rzędzie podlegałyby ewaluacji (testowanie bezpośrednie). Ważne byłoby więc, w jaki sposób, tj. za pomocą jakich środków (kryterium - wykorzystanie stosownego do poziomu zaawansowania wypełnienia leksykalnego), z jaką precyzją (kryterium - złożoność wykorzystanych struktur i ich idiomatyczna formuliczność) cel został osiągnięty. By sprawdzaniu podlegało słownictwo zinternalizowane, uczący się powinni przystępować do realizacji zadania bez uprzedniego przygotowywania się, a jedynie po zapoznaniu się z instrukcją (spontaniczność wymaga odwoływania się do wiedzy implicytnej).

Udzielając uczącym się informacji zwrotnych dotyczących realizacji zadań, należałoby zwrócić uwagę nie tylko na jej mocne czy słabe strony. Bardzo pouczające byłoby również pokazanie im przykładowego rozwiązania. Celem analizy porównawczej obu wersji, własnej, uczących się, i 'modelowej', byłoby skłonienie ich do refleksji nad zasobnością słownika mentalnego, stopniem znajomości 
i wielkością tworzących go jednostek, w konsekwencji zaś - do intensyfikacji pracy nad leksyką.

Wykorzystywanie otwartych zadań komunikacyjnych do ewaluacji słownictwa nie jest zadaniem łatwym ze względu na duży nakład pracy niezbędny do ich właściwego przygotowania, czasochłonność realizacji, a także konieczność opracowania niekonwencjonalnych i niejednokrotnie jednorazowych kryteriów ich oceny. Ocena zaś, by była w pełni obiektywna, wymaga nagrywania, odsłuchiwania nagrań i ich szczegółowej analizy oraz wyczerpującej informacji zwrotnej. Dużo prostsze i mniej czaso- oraz pracochłonne jest natomiast poszerzenie spektrum technik i ich ukomunikacyjnianie (co pokazano na przykładach), które można widzieć jako krok pierwszy w kierunku, w jakim, w moim przekonaniu, warto podążać.

\section{PODSUMOWANIE}

Celem niniejszego tekstu było spojrzenie na zagadnienie testowania słownictwa przez pryzmat jego nauczania. Jak wynika z obserwacji badawczych i codziennej praktyki dydaktycznej, ocenianie stopnia znajomości leksyki pozostaje wprawdzie w zgodności ze sposobami nauczania, te jednak nie zawsze odpowiadają potrzebom uczących się, zwłaszcza na poziomach B2-C2. Pewna modyfikacja stosowanych dotychczas rozwiązań wydaje się więc wręcz konieczna. Po pierwsze, kształcenie powinno w większym stopniu koncentrować się na strukturach leksykalnych, a nie na pojedynczych wyrazach i jeszcze intensywniej angażować uczących się w celowe (nauczanie bezpośrednie), uwikłane kontekstowo działania, które, choć zachodzą w klasie, mogłyby z powodzeniem wydarzyć się w rzeczywistości; po drugie, nauczanie nie powinno przebiegać w układzie równoległym do gramatycznego, lecz w bardziej pożądanym, gdyż daleko efektywniejszym, systemie zintegrowanym (zob. Lipińska, Seretny 2013; Seretny, Stefańczyk 2015); po trzecie - należy w szerszym zakresie rozwijać autonomię uczniów (Dźwierzyńska 2012; Seretny 2015a). Wówczas nauczanie bardziej przystawałoby do potrzeb uczących się, którzy nieustannie skarżą się na brak słów i płynności w posługiwaniu się językiem.

Jako zapoczątkowanie innego myślenia o komponencie leksykalnym widziałabym włączenie do sprawdzianów zadań sprawdzających stopień opanowania słownictwa w sposób bardziej komunikacyjny, ich obecność w sposób naturalny doprowadziłaby bowiem do modyfikacji dotychczasowych metod nauczania leksyki. Cykl taki obserwowaliśmy w glottodydaktyce polonistycznej w związku z wprowadzeniem w życie certyfikacji znajomości naszego języka. Określone zadania najpierw pojawiły się w testach. To spowodowało konieczność wprowadzenia ich do praktyki dydaktycznej (by potencjalni kandydaci mogli sobie z nimi poradzić), a w rezultacie przyniosło zmiany $\mathrm{w}$ procesie kształtowania określonych 
umiejętności/kompetencji/strategii (zob. Lipińska, Seretny 2005). Gdyby więc podobnie stało się z dydaktyką leksyki, zaowocowałoby to optymalizacją procesu nauczania, służącą nie tylko temu, co w klasie, ale przede wszystkim temu, co poza nią (zob. Pawlak 2019a).

\section{BIBLIOGRAFIA}

Aitchison J., 1994, Words in the Mind. Introduction to the Mental Lexicon, Oxford.

Bartmiński J., 2004, Tekst jako przedmiot tekstologii lingwistycznej, w: J. Bartmiński, S. Niebrzegowska-Bartmińska (red.), Tekstologia. Wspótczesna polszczyzna. Wybór opracowań, Lublin, s. $9-24$

Coady J., 1993, Research on ESL/EFL Vocabulary Acquisition. Putting it in Context, w: T. Huckin, M. Haynes, J. Coady (red.), Second Language Reading and Vocabulary Learning, Norwood, New Jersey, s. 3-23.

Dakowska M., 2001, Psycholingwistyczne podstawy dydaktyki języków obcych, Warszawa.

Dyduchowa A., 1988, Metody kształcenia sprawności językowej uczniów. Projekt systemu, model, podręcznik, Kraków.

Dźwierzyńska E., 2012, Sposoby optymalizacji materiału leksykalnego w procesie nauczania języka obcego, Rzeszów.

Ellis R., 2005, Measuring implicit and explicit knowledge of a second language: A psychometric study, „Studies in Second Language Acquisition”, nr 27, s. 141-172.

ESOKJ - Europejski system opisu ksztatcenia językowego: uczenie się, nauczanie, ocenianie, 2003, Warszawa.

Fields R.D., 2004, Drugi mózg, Warszawa.

Glosariusz terminów z zakresu testowania biegłości językowej, thum. M. Gaszyńska-Magiera, A. Seretny, Kraków 2004.

Janowska I. i in. (red.), 2011, 2016, Programy nauczania języka polskiego jako obcego. Poziomy A1-C2, Kraków.

Kjellmer G., 1991, A mint of phrases, w: K. Aijmer, B. Altenberg (red.), English Corpus Linguistics, London, s. 111-127.

Komorowska H., 2019, Ocenianie w nauczaniu języków obcych. Fakty, mity i trudności, „Neofilolog", nr 53/2, s. 9-26.

Lewis M., 1997, Pedagogical Implications of the Lexical Approach, w: J. Coady, T. Huckin (red.), Second Language Vocabulary Acquisition, Cambridge, s. 255-270.

Lipińska E., Seretny A., 2005, Od Z do A, czyli od certyfikacji do programów nauczania, w: P. Garncarek (red.), Nauczanie języka polskiego jako obcego i kultury polskiej w nowej rzeczywistości europejskiej, Warszawa, s. 31-41.

Lipińska E., Seretny A., 2013, Integracja kompetencji lingwistycznych w glottodydaktyce na przykładzie języka polskiego jako obcego/drugiego, Kraków.

Mirocha P., 2019, Listy frekwencyjne jako narzędzie ewaluacji leksyki w podręcznikach do języka polskiego jako obcego. Analiza i ocena podręcznika „Krok po kroku”, „Kwartalnik Polonicum", nr 4, s. 38-45.

Nation P., 2001, Learning Vocabulary in Another Language, Cambridge.

Państwowa Komisja Poświadczania Znajomości Języka Polskiego jako Obcego, 2016, Standardy wymagań egzaminacyjnych, Warszawa.

Pawlak M., 2019a, Skuteczne ocenianie gramatyki: Od tradycyjnych testów do zadań komunikacyjnych, ,Neofilolog”, nr 53/2, s. 171-184 
Pawlak M., 2019b, Tapping the distinction between explicit and implicit knowledge: Methodological issues, w: B. Lewandowska-Tomaszczyk (red.), Contacts \& Contrasts in Educational Contexts and Translation, Cham, s. 45-60.

Pawley A., Syder F.H., 1983, Two puzzles for linguistic theory: nativelike selection and nativelike fluency, w: J.C. Richards, R.W. Schmidt (red.), Language and Communication, London, s. 191-226.

Prizel-Kania A., 2013, Rozwijanie sprawności rozumienia ze stuchu w języku polskim jako obcym, Kraków.

Richards J., 1976, The Role of Vocabulary Teaching, “TESOL Quarterly”, nr 1, s. 77-90.

Seretny A., 2005, Łączliwość leksykalna w nauczaniu języka polskiego jako obcego, w: M. Dąbrowska (red.), Język trzeciego tysiaclecia III, t. 3: Język polski i języki obce-kontakty, kultura, dydaktyka, Kraków, s. 303-312.

Seretny A., 2011a, Kompetencja uczących się języka polskiego jako obcego w świetle badań ilościowych, Kraków.

Seretny A., 2011b, Podejście leksykalne Michaela Lewisa a glottodydaktyka polonistyczna, „LingVaria", nr 1, s. 281-296.

Seretny A., 2013a, Czytanie ekstensywne, czyli sposób na efektywne rozwijanie kompetencji leksykalnej uczacych się, w: A. Achtelik, J. Tambor (red.), Sztuka to rzemiosło. Nauczyć Polski i polskiego, Katowice, s. 208-220.

Seretny A., 2013b, Funkcja czytania ekstensywnego w procesie kształcenia językowego, w: J. Mazur, A. Małyska, K. Sobstyl (red.), Glottodydaktyka polonistyczna w obliczu dynamiki zmian językowo-kulturowych i potrzeb społecznych, t. 2, Lublin, s. 229-236.

Seretny A., 2015a, Słownictwo w dydaktyce języka. Świat słów na przykładzie języka polskiego jako obcego, Kraków.

Seretny A., 2015b, W ciemnościach tunelu, czyli o zjawisku leksykalnego plateau, „Postscriptum Polonistyczne", nr 2(16), s. 89-106.

Seretny A., 2016, Stownictwo polskie w ćwiczeniach dla obcokrajowców, Kraków.

Seretny A., Stefańczyk W., 2015, Między słownikiem a gramatyka - słowotwórstwo w perspektywie glottodydaktycznej, „Postscriptum Polonistyczne”, nr 2, s. 45-62.

Sinclair J., 1991, Corpus, Concordance, Collocation, Oxford.

Wray A., 2002, Formulaic Language and the Lexicon, Cambridge.

\section{Anna Seretny}

\section{TESTING LEXICAL COMPETENCE IN THE CONTEXT OF ITS TEACHING: NEEDS AND REALITY}

Keywords: vocabulary testing/teaching, lexical competence, explicit/implicit knowledge, communication tasks

Abstract. Lexical competence of intermediate and advanced learners of Polish as a foreign language is usually tested by means of tasks which focus on the form and meaning of items and not on their use. This kind of evaluation checks mostly learners' declarative knowledge that cannot be applied under pressure. A fluent and adequate reaction in authentic situations requires implicit (or highly automatized declarative) knowledge based on such an organization of the mental lexicon in which, beside single words, formulaic expressions are stored. The purpose of the article is an analysis of vocabulary teaching/testing at the B2 level in the context of learners' needs. The author argues that traditional tests should be complemented by tasks which; (i) necessitate the use not only of specific words but also of formulaic language, (ii) engage learners in a quasi-natural communication. Such tasks could help to evaluate their implicit vocabulary knowledge and their use in tests could in turn have a beneficial effect on the way vocabulary is taught in Polish. 